\title{
Study on College Students' Employment Ability Promotion Pattern under Innovation and Starting up Business Background Yu-Qiao MENG
}

Jilin Teachers Institute of Engineering and Technology, Triumph Road No. 3050, changchun, 130052. China

942970277@qq.com

Keywords: Employment Ability, Mass innovation and starting up business by millions of people, Promotion pattern.

\begin{abstract}
This article analyzes the current situation of College Students' employment and innovation and entrepreneurship education, points out the existing problems in talent employment oriented education, put forward a college students' employment ability promotion pattern under " Mass innovation and starting up business by millions of people " guidance through the implementation of promoting the employment of college students to improve the ability of.
\end{abstract}

\section{Introduction}

With the popularization of higher education, the number of graduates from regular higher educational institutions are increasing year by year. Up to 2016, the number of graduates has reached 7560 thousand with no obvious increased employment rate. With the step by step boost and practice of national policies such as "Mass innovation and starting up business by millions of people”, higher educational institutions can seize the opportunity to integrate the innovation and starting up business education and professional education, realizing resource sharing, enhance actively education and teaching reform aiming at college students' employment ability promotion, and shoulder the significant responsibility and mission for fostering innovation talents.

\section{College Students' Employment Status Analysis}

Higher education talent development has completed the transition from the previous elite stage to the present popularized stage, while social demand on new graduates are still in a state of "Semi-elite", and this resulted in the situation that enterprises cannot recruit the right talents and graduates cannot find jobs even though there are a mass of graduates and employment opportunities. The circumstance of employment squeeze and recruitment tension has a lot to do with the talents cultivation and education pattern of higher educational institutions and college students' self-knowledge error.

\section{Problems existed in Talents Cultivation Pattern of Higher Educational Institutions}

Education and teaching reform in higher educational institutions has been lasting too many years, transforming the simple and closed theory teaching into the diversified college-enterprise cooperation pattern, including order cultivation, “ $3+1$ ” pattern, and so on. Practice and employment ability of college students has been promoted in a certain degree. However, students who participated in the cooperation between colleges and enterprises are required to pay a high fee for "study", and even cooperation between some colleges and enterprises looks good but lack real worth, their cooperation cannot realize students' further enhance on individual professional skills and employment ability. For most students who have not participated in the cooperation between colleges and enterprises, all of their studies and internships are still the traditional "theory +practice" teaching pattern, so students’ comprehensive qualities cannot be improved. 


\section{Problems Existed in Employment and Starting up Business Education Guidance of Higher Educational Institutions}

Employment and starting up business courses in higher educational institutions are always arranged in the last year of university, lacking systematic, periodical and thoroughly guidance. Some institutions only deal with it carelessly through holding just one or two lectures. For teaching staffs, the tasks of guidance courses are mainly completed by instructors or teachers who are responsible for employment. Many times, their own majors do not match students' majors. They have not a deeply understanding on students' majors and lack enough research on social demand, resulting in a blurry guidance on students' employment directions. All these problems have caused that college students' employment education results cannot be guaranteed. In the aspect of starting up business education, almost all of the guidance teachers are vocational teachers who lack experiences of starting up business. So the guidance equals "Be an armchair strategist".

\section{Study on Status of Innovation and Starting up Business Education and Teaching in Higher Educational Institutions}

General Office of the State Council issued "Execution Opinions on Enhancing Higher Educational Institutions Starting up Business and Innovation Education Reform” (Guobanfa〔2015〕 No. 36) on May 4, 2015, planning higher educational institutions' starting up business and innovation education reform task field. By the first half year of 2015, the State Council had been continuingly is suing a series of aid measures concerning cohesion of force to promote "mass innovation and starting up business by millions of people", to boost our country's "Start up business by millions of people, mass innovation” project. Although some higher educational institutions' innovation and starting up business education has been executed for years, statistics show that college students who really execute to start up business in those that tend to choose to start up business are less than one out of ten in China, the average success rate is about $2 \%$. The highest success rate is only $4 \%$ (Zhejiang province), which has a huge gap from that of Europe and America which is about 20\%. Although higher educational institutions' innovation and starting up business education has achieved a result through promoting vigorously for years, some problems that cannot be neglected and need to be improved still exist in the course of execution.

\section{Shortage of Innovation and Starting up Business Courses Setting}

Higher educational institutions has offered courses relating to innovation and starting up business, but a serious shortage exist in courses' time arrangement and contents. Many institutions have not taken the course as the whole colleges' general curriculum. Class hours are few. Class contents are single. Teaching patterns are mainly team discussion and case analysis, and it is hard to reflect the meaning of innovation and starting up business education. Students lack study interests, and they cannot obtain knowledge and experiences for starting up business through this impractical method.

\section{Innovation and Starting up Business Education Activity Becomes a Mere Formality}

Innovation and starting up business education activities should be completed in the form of connection of class teaching and after-class practice, and the after-class practice should be emphasized. At present, higher educational institutions' innovation and starting up business courses still tend to be the traditional teaching method, and neglect the after-class practice for students' personal experiences content. "National Innovation”, “Challenge Cup" and other activities held each year are only reflected on paper, rather than realizing real innovation and starting up business. Many colleges set up innovation and starting up business base, hatch garden. However, these failed to develop successfully resulting from limited conditions in fund, sites, projects, and so on. Projects initiated by students with innovation and starting up business dream have not been supported and cultivated sufficiently. 


\section{Innovation and Starting up Business Teachers' Team Force is Poor}

Innovation and starting up business is aimed at fostering excellent college students under the guidance of teachers with innovation and starting up business experience, and teachers are required to have innovation ability and starting up business experience, instead of common college teachers, being good for students' innovation and starting up business development. Innovation and starting up business teachers in colleges are usually completed by instructors who are inexperienced in whether class teaching or practice teaching, and their abilities are not enough, not to mention to guide students in such aspects of skills and thoughts in innovation and starting up business.

\section{Students’ Cognitive Differences on Innovation and Starting up Business}

College students do not understand innovation and starting up business courses, they don't think innovation and starting up business courses have something to do with them, but just obtain credits. Some students who participate in innovation and starting a business competition activities just complete rigidly their work under the guidance of teachers, rather than link it to their own major, employment and even their future occupation. Hence, college students' wrong understanding has limited their development of innovation and starting up business.

\section{Study on College Students' Employment Ability Promotion Pattern Based on the Background of Innovation and Starting up Business}

Under the guidance of the spirit of "Mass innovation and starting up business by millions of people”, higher educational institutions' innovation and starting up business education has become an important content in higher education, connecting innovation and starting up business education with college students' employment, and doing well in higher educational institutions' education reform innovation is an effective path of enhancing employment abilities of college students.

\section{Integrating Innovation and Starting up Business Education with Professional Education}

College education has set up starting up business education, but it has been separated with professional education. Professional teachers pay more attention to imparting theoretical knowledge and they always tend to neglect the relation and connecting between theoretical knowledge and students' occupation plan and development direction in the future. Starting up business teachers focus on practice and cultivation of students' starting up business consciousness, starting up business spirit and occupation quality. However, school teaching serious dislocated from social demand, quality of talent cultivation are decreased and students' manipulative ability and social practice ability seriously are inadequate due to starting up business education are separated from the platform of professional knowledge. Therefore, if colleges intend to promote students' employment ability through innovation and starting up business education, traditional courses setting should be changed, innovation and starting up business education and professional education resource need to be integrated and shared to take fostering and improving students' comprehensive quality and ability as the core, adhere to take the professional education as the fundamental, guarantee the leading role of professional and innovation and starting up business education courses' contents and forms to lead students to master solid theoretical knowledge, and strengthen students' innovation spirit, starting up business quality and form occupational quality for promoting employment ability of students.

\section{Strengthening Innovation and Starting up Business Teachers Team Building}

College professional teachers are famous for their scientific research capacities. In the aspect of giving lessons, they always focus on "giving" and neglect "lead". Innovation education tend to paying attention to students' new thoughts and ideas based on the current knowledge, all of which needs teachers to provide correct guidance and inspiration. Many teachers possess strong self-research ability but they are inadequate in leading and fostering students' innovation ability. Teachers who are engaged in starting up business education lack employment and starting up business experience, not mention to specifically guide students to start up business and take up an 
occupation. Therefore, first of all, professional teachers' innovation ability should be strengthened to encourage and lead students to work on innovation research and result transformation together with them. In the aspect of starting up business, it is necessary to introduce entrepreneurs or noted public figures who have rich starting up business practice or occupational experiences to work on starting a business guidance and education, influence students through their own experiences, answer questions from students according to their own experience, strengthen students' confidence for starting up business, and enhance their employment and starting up business ability.

\section{Organizing Diversified Practical Training Activities}

It is difficult to realize the promotion of college students' employment ability only depending on teachers' guidance and teaching. Such ability can only be improved through practices. Promoting college students' employment by innovation and starting up business education requires attaching importance to the training of students' manipulative and practical training ability, taking the laboratory, internship and practical training base, starting up business project, innovation and starting up business competition and other activities as the carrier to execute targeted and personalized guidance and training, foster and promote students' starting up business practical ability and post adaptation ability in real scenes, and then students' employment ability will be improved.

\section{Conclusion}

Promotion of college students' employment ability is one of the standards inspecting whether or not the college education is successful. Fostering high quality talents whose professional skills, innovation and starting up business abilities and comprehensive qualities are strong taking full advantage of colleges' professional education resources under our country's guidance spirit of "Mass innovation and starting up business by millions of people" is the significant aim for training talents of higher education institutions. Practice of college students' employment ability promotion pattern under the background of innovation and starting up business will promote college students' ideologies and personal qualities step by step, their career competitiveness will be stronger and stronger, and their employment ability will be improved greatly.

\section{References}

[1] Z.G.Gao, Y.Zhan, G.Wang, On the Construction of the College Teaching System of Innovation and Entrepreneurship Education Course, (263)2016

[2] J.Qian, Problems Reflection and Countermeasures Selection of Universities' Innovation and Entrepreneurship Education, Higher Vocational Education Exploration,(6)2016

[3] Z.G.Ren, H.Mei, Higher Education Reform Research in the New Era of Innovative and Entrepreneurial,(1)2017 